\title{
Innovative Financial Instruments and mechanisms for financing forest restoration and mitigating climate change: select cases from India
}

\author{
Teki Surayya $^{1}$
}

\section{Abstract}

Climate Change (CC) is universal concern. One of the causes for CC is degradation of forest. World over every minute 22 hectares forest is degraded. Reckonings suggests that US\$11880, funds must be invested every minute to restore the forest.

In India Atmospheric pollution has severed in 90's because of increased automobiles and electronic goods. Green car congress reported level of NO2 concentration in Delhi ranged 70 - 102 microgram per cm, in 2005. It is argued that the consumers are capable of meeting part of cost of CC mitigation. Recent survey (Teki, 2008) in National Capital Region revealed that $40 \%$ of sample preferred to compensate through tax on petroleum products, $22 \%$ in investing in forestry bonds, $57 \%$ favoured compulsory investment in bonds. Awareness rate about climate change was $92 \%$, and $88 \%$ favoured both technology transitions and economic sanctions for mitigating CC. Evolving innovative financing instruments and mechanisms to finance forest restoration and mitigating CC is important.

Timber was considered important contribution of forests, as 2\% GDP comes to exchequer. NTFPs now considered equally important for forest restoration as $25-55 \%$ of forest living people survival comes from NTFPs. Forests have innovative financial instruments like Eco-tourism, to finance forest restoration. Self reliance apart from the government funding and the private funding. Mobilisation of savings, bank finance, creating/strengthening global carbon fund effectively and financing the substitute sectors are important for restoration of ecological integration and productivity and economic value of deforested or degraded land. Objectives of paper are: a) to assess level and impact of forest degradation and forest restoration in India, b) to translate carbon pollution level into mitigating CC, b) awareness level of CC in NCR c) measure willingness of consumers to compensate for $\mathrm{CC}$, and $\mathrm{d}$ ) evolve innovative financial instruments and mechanisms to finance sustainable forest restoration in India.

Key words: Financing, Forest restoration, Climate change, Mitigation, Forestry services

${ }^{1}$ Professor and Head, Department of Management Studies. Adikavi Nannaya University, Rajahmundry, A.P. State, India. Phone:+91-883-2472616, fax:91-883-2472615, Mobile: 91-8121692457.

Email: tekisunny@gmail.com teki9@,rediffmail.com 


\section{Introduction}

Climate change (CC), as an issue has risen from the annals of esoteric scientific discussion in the 70's and 80's to the coffee table discussions in the late 90's. This change has come about because of increased awareness and concern among people. Increase of carbon content in the atmosphere is a primary cause of CC as a consequence of deforestation and atmospheric pollution. People have come to understand the long-term effect of CC. A survey by Roper Starch World-wide (Ottman 1998), conducted primarily in the USA, reported the top ten "very serious" environmental concerns of the consumers as: industrial water pollution, 2) destruction of ozone, 3) destruction of rain forest, 4) industrial accidents, 5) hazardous waste, 6) oil spills, 7) industrial air pollution, 8) radiation from nuclear power plant accidents, 9) drinking water contamination, and 10) ocean contamination. However in Indian context in the absence of any such report, major environmental and forest degradation can be classified as having been caused by industrial or non-industrial sources. Industrial sources are water, air, and ground pollution caused as a result of industrial activity. Non-industrial sources are carbon release due to deforestation, atmospheric pollution from use of manufactured goods such as automobile emissions, pollution from other non-industrial activities such as sewage disposal, etc. Automobiles in India account for a lion's share of nonindustrial environmental pollution. Atmospheric pollution from this source has become severed in the 90's as the number of automobiles in India has increased exponentially. Automobile traffic in New Delhi is a case in point; air pollution from automobiles in New Delhi is of the proportion that is has become almost a necessity to wear a gas mask if driving a vehicle. To confirm this vehicle driver is reported to have quipped that waiting at traffic lights is like being inside a gas chamber. According to a study, (www.greencarcongress.com) the level of NO2 concentration in New Delhi ranged from 70 to 102 microgram per cubic meter in the first week of February 2005, whereas the standard limit is 80 microgram per cubic meter. During the same period in 2002, this figure ranged from 72 to 85 microgram per cubic meter The phenomenal growth in automobile in India is directly related to economic growth and hence, growth in disposable income with people. However, this should not mean that we remain oblivious of the damage to environment. For example, Gandhi (1998) expressed that development that leads to the destruction of environment runs the risk of destroying itself. He added further that conserving the environment must be a focus of development in order to reap the fruits of development. Thus, we must find ways to reduce pollution: directly by improving technology, and indirectly by sequestering carbon through restoration of forests, that requires financial outlays. 
As a first step, it may seem feasible that automobile industry and users, in time, should become aware of the pollution caused by them and the cost associated with cleaning such pollution. One of the easiest way to get rid of the excess carbon indirectly from the atmosphere is through sequestering them in forests and cost associated, at least partly, be met by such pollutant- the automobile industry and auto mobile consumers - on the principle that the destroyer invariably must pay for the damage. That is, raising trees as plantation, forest restoration, or tree farming not only would clean the air of excess carbon, but may also mitigate the CC and also spin off benefit it helps to meet the wood or fibber requirement of the society. Therefore, automobile industry, and automobile users, who are major contributors of carbon pollution in air and CC, should become a contributor to the national afforestation and forest restoration efforts. Amount of carbon released by various kinds of automobiles have been estimated and is available as secondary data. Carbon content in a tress is typically $45 \%$ by weight (Shrivastava 1998) and it can be sued as a shadow price to determine the contribution of automobile industries and auto users. People owning automobiles may be characterized as having sufficient disposable income that enabled them to spend money such goods. Thus it may be argued that they are capable of meeting part of the cost cleaning such pollution and mitigating CC. Therefore, following objectives have been envisaged in the study. a) to assess level and impact of forest degradation and forest restoration in India, b) to translate carbon pollution level into mitigating $\mathrm{CC}, \mathrm{b}$ ) awareness level of CC in NCR c) measure willingness of consumers to compensate for CC, and d) evolve innovative financial instruments and mechanisms to finance sustainable forest restoration in India.

\section{RESEARCH METHODOLOGY}

This study embodies both primary and secondary data. Pertinent secondary data on sustainable development of forest, forest restoration, role of forest in (particularly were sourced mainly from earlier research works on forests) mitigating and adopting CC, financing and marketability of forest services. An in-depth literature review has been conducted to obtain data from various sources. An attempt was made for comparing available secondary data sources with primary data. The primary data for measuring propensity of consumers/owners of automobiles (automobiles and electronic goods like air-conditions, refrigerators) to support compensatory restoration and other forestry activities were gleaned through a semi-structured questionnaire. The questionnaire was canvassed by face-to-face and telephone interviews to a sample of 300 respondents in New Delhi and Faridabad Cities in the National Capital Region of India, in August-October 2009. The collected data were analyzed using descriptive statistics. 


\section{Results And Discussions:}

\section{Creation of forest restoration and climate change fund}

Forest is a core requirement for survival and growth of all things. Due to increased

TABLE 1 Government of India Central Plan Outlay for Ministry of Environment Forest, Government of India

\begin{tabular}{|c|c|c|}
\hline Year & $\begin{array}{c}\text { Budget / } \\
\text { Revised } \\
\text { estimates } \\
\text { INR. in } \\
\text { million }\end{array}$ & $\begin{array}{c}\text { \% Annual } \\
\text { growth } \\
\text { rate }\end{array}$ \\
\hline $1996-97$ & 45700 & \\
\hline $1997-98$ & 44000 & -03.7 \\
\hline $1998-99$ & 46800 & 06.4 \\
\hline $1999-00$ & 61000 & 30.3 \\
\hline $2000-01$ & 61000 & 0.0 \\
\hline $2001-02$ & 90000 & 47.5 \\
\hline $2002-03$ & 94000 & 04.4 \\
\hline $2003-04$ & 95000 & 01.1 \\
\hline $2004-05$ & 105000 & 10.5 \\
\hline $2005-06$ & 129500 & 23.3 \\
\hline $2006-07$ & 133900 & 3.4 \\
\hline $2007-08$ & 140000 & 4.6 \\
\hline $2008-09$ & 150000 & 7.1 \\
\hline $2009-10$ & 165000 & 10.0 \\
\hline $2010-11$ & 220000 & 33.3 \\
\hline Mean & 105390 & 19.7 \\
\hline
\end{tabular}

Source: httn://indiabudaet.nic.in/

remember always. Therefore restoring forests and reviving the exhausted inventory is indispensable, which requires three different resources such as; a) Physical, b) Human, and c) financial resources. This paper focuses on financial resource required for restoration of forests and mitigating CC. Financing of forest restoration here means everybody of us generously march forward to render financial population and evolved technology, the forests have been unduly exploited that has been causing pollution, ecological imbalance and CC. World over (wwf-1998) every minute approximately 50 acres (22 hectares) of forest cut down. The world loses (WBG-2009) about 13 million hectares of forests each year, (25 hectares per minute, an increase 3 hectare per minute compare to 1998 WWF estimates), much of it in tropical developing nations. To compensate this massacre every minute US $\$ 11880$ as per 1998 estimates and as per 2009 estimates it is US\$ 13500 , funds should be invested for long term sustenance of the forests and mitigating CC. Destruction of these forests, along with other land use activities; result in an estimated 20 percent of the annual global greenhouse gas emissions. The moral is this "Hay while the sun shines" which one should

FIGURE. 1 Central Plan Outlay for Ministry of Environment and Forest

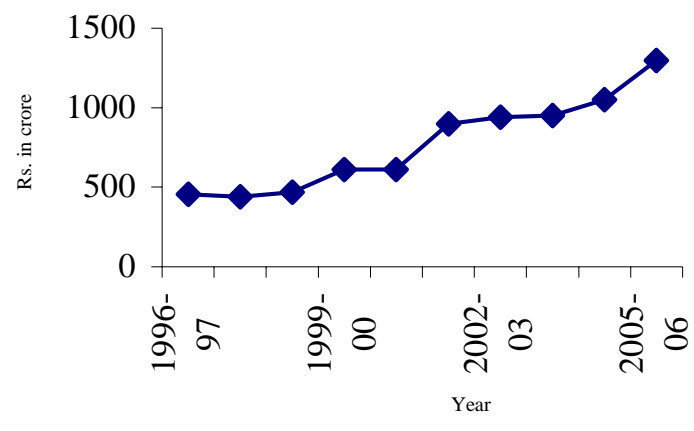


assistance to restore the forests and mitigate CC. Financial investment in forests is defined (www.fao.org) as the "Use of current financial resources to accumulate forest capital assets and thereby expand productive capacity of forests for the future". Secondly where will the financial resources com from (equity and debt)? For natural forestry projects, it come through government budget allocations (in India, on an average 105.39 billion INR p.a. from 1996-97 to 2010-11) are being considered (table 1 and fig. 1 up to 2005-06) to be equity and the other sources like borrowing from market/ public or financial institutions which is not current practice of forest department but need to go for markets if required, like any other public sector agencies, like National Highway Authority of India (NHAI) in India, in the near future. The third area of forestry financial management is profit planning includes how to serve the debt and repaying to the exchequers revenues generated from forests. The design of the global climate policy and finance architecture is also the one of the main focus areas of the ongoing international negotiations toward long-term cooperative action by all countries. Therefore it is essential to create a CC and forest restoration fund of India, (pooling funds from above mentioned innovative financial instruments like green taxes and green cess on petroleum products, and also through issue of long term forestry bonds) in lines with the World Bank's Climate Investment Funds. Forestry has not been (C. Luttrell 2007) popular under the CDM due to high transaction costs and other restrictions. To date, most funding for forestry has occurred through voluntary markets. More recently, there has been increasing international debate over the potential for 'Reducing Emissions from Deforestation and Forest Degradation' (REDD) and the imminent implementation of some pilot schemes with multilateral funding

\section{Climate Change (CC)}

Global view: CC epitomizes the (TWG 2009) complexity of the development challenge in a globalising but still highly unequal world. It magnifies growing concerns about food security, water scarcity, and energy security. In its Fourth Assessment Report, the Intergovernmental Panel on Climate Change (IPCC 2007) made clear that the evidence of the warming of the climate system is unequivocal. Over the last century, there are empirical records of widespread increases in observed air and sea temperatures, sea-level rise, melting sea-ice and glaciers, and reduction of snow cover. Climate change has the potential to reverse the hardearned development gains of the past decades, and impede the progress toward achieving the Millennium Development Goals (MDGs), such as eradicating poverty, combating communicable diseases, and ensuring environmental sustainability. The anticipated impacts of climate change, which could begin to occur within the next two to three decades, include: dangerous floods and storms; exacerbated water stress; decline in agricultural productivity and food security; and further spread of 
water-related diseases, particularly in tropical areas. An effective response to climate change must combine both mitigation - to avoid the unmanageable-and adaptation, to manage the unavoidable (Global estimates and investment requirements for both shown in annexure 2). Most of the warming trend observed since the mid-20th Century is very likely due to an increase in anthropogenic greenhouse gas (GHG) concentrations, particularly of carbon dioxide (CO2) caused by activities such as fossil fuel use and land use changes. While the Earth is likely to already be committed to the level of warming within 2 degrees Celsius, the challenge remains to curtail global greenhouse gas (GHG) emissions so that it will be feasible to "manage the unavoidable" without incurring costs and impacts of a catastrophic magnitude.

Delhi Metro considers (E. Sreedharan-2009) it as a comparative advantage to be able to address the challenges of climate changes as early as possible. If it is left unabated, climate change would most certainly reverse the hard-earned development gains in which the poorest are most likely to suffer the earliest and the most. Some of the major impacts include water scarcity problems, increased intense tropical storm activity, storm surges and hurricanes, food security concerns and adverse health impacts. The most likely causes of global warming and climate change are the anthropogenic greenhouse gas (GHG) emissions, mainly carbon dioxide (CO2) from burning of fossil fuels and changing land use. India is world's fourth largest economy and fifth largest greenhouse gas (GHG) emitter. Transport sector contributes $20-25 \%$ of GHG emissions worldwide. There is therefore a pressing need to scale up support to sustainable transport and urban development programmes.

The massacres (M. Colchester) in Peru and the cyclone in Bangladesh reinforce arguments that forest peoples' rights are central issues both in steps to curb forest loss and in adapting to climate change. 
Forest restoration fund: to meet multiple objectives like attaining 33\% forest cover, through forest restoration, arresting dwindling biodiversity, mitigating CC, and improving livelihoods, creation of forest restoration fund is an essential step that

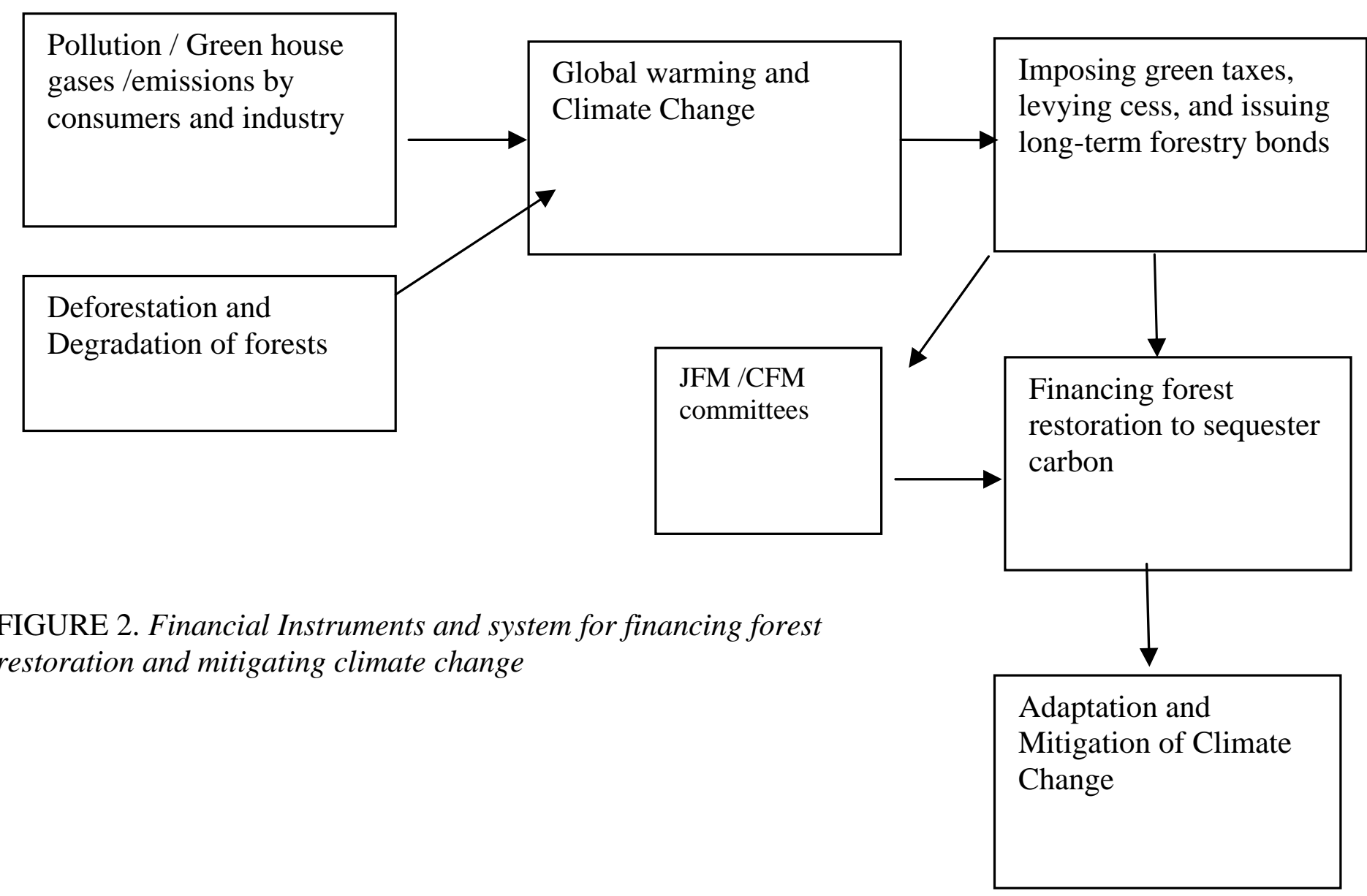

can be initiated by the government of India. Financial resources to be tapped for creating this type of fund can include introducing green taxes, collecting cess on income tax or petroleum products, compulsory investment in forest development bonds, etc. There is global evidence of creating such funds for sustainable forest management. For example, a plantation development fund has been established in Ghana to support plantation development by private sector (Yeboah 2001). In India timber was considered the only important contribution of the forests, that remits sizable revenues amounting to $2 \%$ of India's GDP. NTFPs, such as tamarind, Baubinia vabll leaves, sal (Shorea robusta) leaves and seeds, dammars, resin, butter fats, tannin, Aonla (Emblica officinalis) etc., are gaining importance for sustainable forest management as nearly $80 \%$ of forest dwellers in India depends on NTFPs (Shiva \& Jantan 1998). A large portion, 25 to $55 \%$ of their subsistence is derived from NTFPs harvest, collection and trade. Community involvement (K. Manivong and P Sophathilath-2007) in managing forests and natural resources has been recognised and strongly encouraged by the Government of Lao PDR since the first National 
Forestry conference in1989, emphasizing that the maintenance of the healthy and productive forests is central to the rural livelihoods.

All these are vindication for role of forests in various spheres. Hence, restoration of forest not only mitigates CC but also renders other above said benefits. But the problem is from where does fund for financing forest restoration come? The probable answer can be, augmenting innovative financial instruments, to raise the required outlays. Process of such fund raising system to finance forest restoration and mitigate CC, and also innovative financial instruments to be deployed to raise fund is shown in figure 2. Figure 2 showing the process of creating forest restoration and climate change fund for mitigating and adopting climate change. Pollution / Green House Gases (GHG) emissions generated by consumers while consuming electronic products \& automobiles and industry in the course of manufacturing goods and services, that are one of the primary causes for Global warming and CC. Hence, consumers and industry are responsible for GHG that lead to CC. Therefore they should invariably compensate via innovative financial instruments including paying green taxes and cess directly or indirectly compelling them to invest in long-term forestry bonds, for the damages caused by them to the environment and causing CC. Thus the forestry restoration and CC fund can be created in lines with World Bank's climate investment fund. With the help of this fund forest restoration projects can be financed involving local communities though Joint Forest Management (JFM) committees and Community Forest Management (CFM) committees mechanism for effective and efficient forest restoration and inclusive development, that would eventually helps in mitigation and adoption measures of CC.

A field survey has been conducted with the help of a structured questionnaire that was administered to 300 respondents, to measure the consumers' propensity to compensate for the pollution caused by them. The results of the survey are tabulated in table 2 . The survey reveals that $40 \%$ of respondents preferred to compensate by way of collecting cess on petroleum products, $22 \%$ preferred in investing in low coupon rate long term forestry bonds. More than half $(57 \%)$ of the respondents favoured introducing a compulsory investment in forestry bonds, $20 \%$ preferred the imposition of direct green taxes, $10 \%$ of the sample said that they would prefer cess on income tax and 8\% voted for other instruments. Hence, it can be deduced that policy makers can consider levying cess on petroleum products and issuing forestry bonds as sources for financing forest restoration fund. The awareness rate about pollution /GHG emission caused by them is 100\% in automobile users and $92 \%$ in electronics goods consumption and $88 \%$ of the sample favored both technology transitions (improvements) and forest restoration for carbon sequestration, as CC mitigation and adaptation measure which is in line with global preferences. It is 
pertinent to mention, some other select global example of value of payments for biodiversity are exhibited table 3 below.

TABLE 2. Measuring propensity of consumers (automobile and electronic goods) to support forest restoration fund

\begin{tabular}{|c|c|c|c|c|c|c|c|}
\hline \multirow[t]{2}{*}{ Variable } & \multicolumn{3}{|c|}{ Automobile pollution } & \multicolumn{4}{|c|}{$\begin{array}{l}\text { Electronic goods (air-conditioner, } \\
\text { refrigerator) pollution/ Ozone depletion }\end{array}$} \\
\hline & \multicolumn{2}{|l|}{ Aware } & Not aware & \multicolumn{2}{|c|}{ Aware } & \multicolumn{2}{|c|}{ Not aware } \\
\hline $\begin{array}{l}\text { Rate of } \\
\text { awareness }\end{array}$ & $100 \%$ & \multicolumn{2}{|c|}{0} & \multicolumn{2}{|l|}{$92 \%$} & \multicolumn{2}{|c|}{$8 \%$} \\
\hline \multicolumn{2}{|c|}{$\begin{array}{l}\text { Total number of two } \\
\text { wheelers owned in the } \\
\text { sample }\end{array}$} & \multicolumn{2}{|c|}{185} & \multicolumn{2}{|c|}{$\begin{array}{l}\text { Total number of four } \\
\text { wheelers owned in the } \\
\text { sample }\end{array}$} & \multicolumn{2}{|c|}{115} \\
\hline \multicolumn{2}{|c|}{$\begin{array}{l}\% \text { of respondents own } \\
\text { air-conditioners }\end{array}$} & \multicolumn{2}{|c|}{$33 \%$} & \multicolumn{2}{|c|}{$\begin{array}{l}\% \text { of respondents own } \\
\text { refrigerator }\end{array}$} & \multicolumn{2}{|c|}{$90 \%$} \\
\hline \multicolumn{8}{|c|}{ Preferences of respondents to reduce the pollution } \\
\hline \multicolumn{2}{|c|}{$\begin{array}{l}\% \text { favoured } \\
\text { technology } \\
\text { transitions } \quad 12 \%\end{array}$} & \multicolumn{2}{|c|}{$\begin{array}{l}\% \text { favoured } \\
\text { afforestation } \\
10 \% \\
\end{array}$} & \multicolumn{4}{|c|}{$\begin{array}{l}\% \text { favoured technology transitions and } \\
\text { afforestation } \quad 88 \%\end{array}$} \\
\hline \multirow{2}{*}{\multicolumn{2}{|c|}{$\begin{array}{l}\text { Instrument preferred } \\
\text { for compensating } \\
\text { pollution caused by } \\
\text { sample consumers }\end{array}$}} & $\begin{array}{l}\text { Direct } \\
\text { taxes } \\
\text { (green } \\
\text { tax) }\end{array}$ & $\begin{array}{l}\text { Cess on } \\
\text { income } \\
\text { tax }\end{array}$ & $\begin{array}{l}\text { Cess on } \\
\text { pretroleum } \\
\text { products }\end{array}$ & \multicolumn{2}{|c|}{$\begin{array}{l}\text { Investing in } \\
\text { low coupon } \\
\text { rate long } \\
\text { term } \\
\text { forestry } \\
\text { bond }\end{array}$} & $\begin{array}{l}\text { Other } \\
\text { insutrument }\end{array}$ \\
\hline & & $20 \%$ & $10 \%$ & $40 \%$ & $22 \%$ & & $8 \%$ \\
\hline \multicolumn{2}{|c|}{$\begin{array}{l}\text { Compulsory } \\
\text { investment in } \\
\text { forestry bonds }\end{array}$} & \multicolumn{2}{|c|}{ Favoured $57.2 \%$} & \multicolumn{3}{|c|}{ Not favoured $42.8 \%$} & \\
\hline
\end{tabular}

Source: field survey 2009 
TABLE 3 Value of payments for biodiversity conservation: selected examples

\begin{tabular}{|c|c|c|c|}
\hline Payment scheme & Country & Type of payment/commodity & Estimated value \\
\hline $\begin{array}{l}\text { Critical } \\
\text { Ecosystems } \\
\text { Partnership (World } \\
\text { Bank, } \\
\text { Conservation } \\
\text { International, } \\
\text { Global } \\
\text { Environment } \\
\text { Facility) }\end{array}$ & $\begin{array}{l}\text { Developing } \\
\text { countries }\end{array}$ & $\begin{array}{l}\text { Fund to finance diverse groups to } \\
\text { protect biodiversity }\end{array}$ & $\begin{array}{l}\text { US } \$ 150 \text { million } \\
\text { capitalization }\end{array}$ \\
\hline $\begin{array}{l}\text { Ejido financing of } \\
\text { local pas- } 7 \text { million } \\
\text { hectares }\end{array}$ & Mexico & & US\$14 million \\
\hline $\begin{array}{l}\text { BOCOSA Project } \\
\text { (Osa Penninsula) }\end{array}$ & Costa Rica & $\begin{array}{l}\text { Payments to farmers to conserve their } \\
\text { lands }\end{array}$ & $\begin{array}{l}\text { US } \$ 24 / \text { hectare } \\
\text { /year }\end{array}$ \\
\hline $\begin{array}{l}\text { Payment for } \\
\text { environmental } \\
\text { services }\end{array}$ & Costa Rica & $\begin{array}{l}\text { Compensation to forest owners for the } \\
\text { ecosystem services of their lands, as } \\
\text { included in } 1996 \text { Forest Law }\end{array}$ & $\begin{array}{l}\text { US } \$ 221 \text { - } \\
344 / \text { hectare/year } \\
\text { Total: US } \$ 14 \\
\text { million }\end{array}$ \\
\hline $\begin{array}{l}\text { Shade-grown } \\
\text { coffee }\end{array}$ & $\begin{array}{l}\text { Mesoame- } \\
\text { rica }\end{array}$ & $\begin{array}{l}\text { Coffee trees grown among other trees, } \\
\text { enhancing biodiversity }\end{array}$ & $\begin{array}{l}\text { US\$ billion for } \\
\text { sale of shade- } \\
\text { grown coffee in } \\
\text { US alone }\end{array}$ \\
\hline $\begin{array}{l}\text { Privately protected } \\
\text { areas }\end{array}$ & Chile & $\begin{array}{l}\text { Private investments in } \backslash \text { land } \\
\text { conservation including: private parks, } \\
\text { land donations to national park system, } \\
\text { conservation communities, eco-real } \\
\text { estate and ecotourism, and private } \\
\text { administration of government } \\
\text { conservation lands }\end{array}$ & $\mathrm{NA}$ \\
\hline Wetland banking & US & $\begin{array}{l}\text { Developers who have mitigated off-site } \\
\text { draw from bank of 'mitigation' credits } \\
\text { to offset damage to wetlands as } \\
\text { development is implemented }\end{array}$ & $\begin{array}{l}\text { US } \$ 7,500- \\
100,000 / \text { acre } \\
\text { (cost of banking } \\
\text { credits) }\end{array}$ \\
\hline Bioprospecting & Worldwide & $\begin{array}{l}\text { Biodiversity prospecting, primarily } \\
\text { pharmaceutical, to market products and } \\
\text { conserve forests }\end{array}$ & $\begin{array}{c}\text { US } \$ 17.5 \\
\text { billion9natural - } \\
\text { product drugs) }\end{array}$ \\
\hline $\begin{array}{l}\text { Ecological value- } \\
\text { added tax }\end{array}$ & Brazil & $\begin{array}{l}\text { Mechanism that compensates } \\
\text { municipalities that have conservation } \\
\text { areas. Stimulates improvement of } \\
\text { existing areas or creation of new areas }\end{array}$ & $\begin{array}{l}\text { US\$150 million } \\
\text { (Prana State) } \\
\text { US\$45 million } \\
\text { (Minas Gerais) }\end{array}$ \\
\hline
\end{tabular}

Source: S. Scherr, A. White \& A. Khare, 2004 


\section{Innovative instruments to finance sustainable forest development and forest restoration select global cases:}

The financing and overall management of natural forests are traditionally responsibilities of national governments. But in the recent past forestry sectors are experiencing decrease in public financial resources to finance and manage the natural forests. From data in Table 4 reproduced from Khare (2003), it can be inferred that the official development assistance for sustainable forest decreased by almost $100 \%$ (US $\$ 2-2.2$ billion in early 1990s to $1-1.2$ billion in early 2000s), and that for protected areas was US $\$ 700-770$ in early 90 s to $350-420$ in early 2000 s, about $48 \%$ decrease. Whereas philanthropic sources of financial flow has posted an increase of about $75 \%$, and communities sources were also posted tremendous increase of about $356 \%$, between the same periods.

TABLE 4. Estimated financial flows for forest conservation (US\$)

\begin{tabular}{|c|c|c|c|c|}
\hline Source of finance & $\begin{array}{c}\text { Sustainable forest } \\
\text { management (early } \\
\text { 1990s) }\end{array}$ & $\begin{array}{c}\text { Sustainable } \\
\text { forest } \\
\text { management } \\
\text { (early 2000s) }\end{array}$ & $\begin{array}{c}\text { Protected } \\
\text { areas (early } \\
90 \mathrm{~s})\end{array}$ & $\begin{array}{c}\text { Protected } \\
\text { areas (early } \\
2000 \mathrm{~s})\end{array}$ \\
\hline $\begin{array}{c}\text { Official } \\
\text { development } \\
\text { assistance }\end{array}$ & $\begin{array}{c}2 \text { billion- } \\
2.2 \text { billion } \\
1.2 \text { billion }\end{array}$ & $\begin{array}{c}700 \\
\text { million- } \\
770 \\
\text { million }\end{array}$ & $\begin{array}{c}350 \\
\text { million- } \\
420 \\
\text { million }\end{array}$ \\
\hline $\begin{array}{c}\text { Public } \\
\text { expenditure }\end{array}$ & NA & 1.6 billion & NA & $\begin{array}{c}598 \\
\text { million }\end{array}$ \\
\hline Philanthropy* & 85.6 million- & 150 million & NA & NA \\
\hline Communities ** & 365 million & 1.3 billion & NA & NA \\
\hline
\end{tabular}

Source: Khare (2003) as reproduced by S. Scherr, A. White \& A. Khare (2004).

* Including self-financing and in-kind NGO contributions

** Self-financing and in-kind contributions from indigenous and other local communities.

$\mathrm{NA}=$ not available

\section{Role of forest restoration in mitigating climate change}

Forests play important role in carbon sequestration. Primary forests are greater sources of carbon sequestration, followed by logged forest, shifting cultivation, complex and simple agro-forestry (Figure 3). All national and global agencies should strive to protect and enhance the health of primary forests and forest cover as it is 
not only the greater source of carbon sequestration and mitigating CC, but also provides many direct vital services like, supply of timber, non-timber forest products, soil conservation, wildlife habitat, maintaining tribal culture, etc. Restoring and protecting forests will also contribute to industrial/economic development as they sequester carbon, industries can then produce more. Increasing industrial production means more emission but that can be offset with increased forests restoration efforts without contributing to global warming and climatic changes. Investment in forests may have greater benefits vis-à-vis investment in other instruments like fuel-efficient technology.

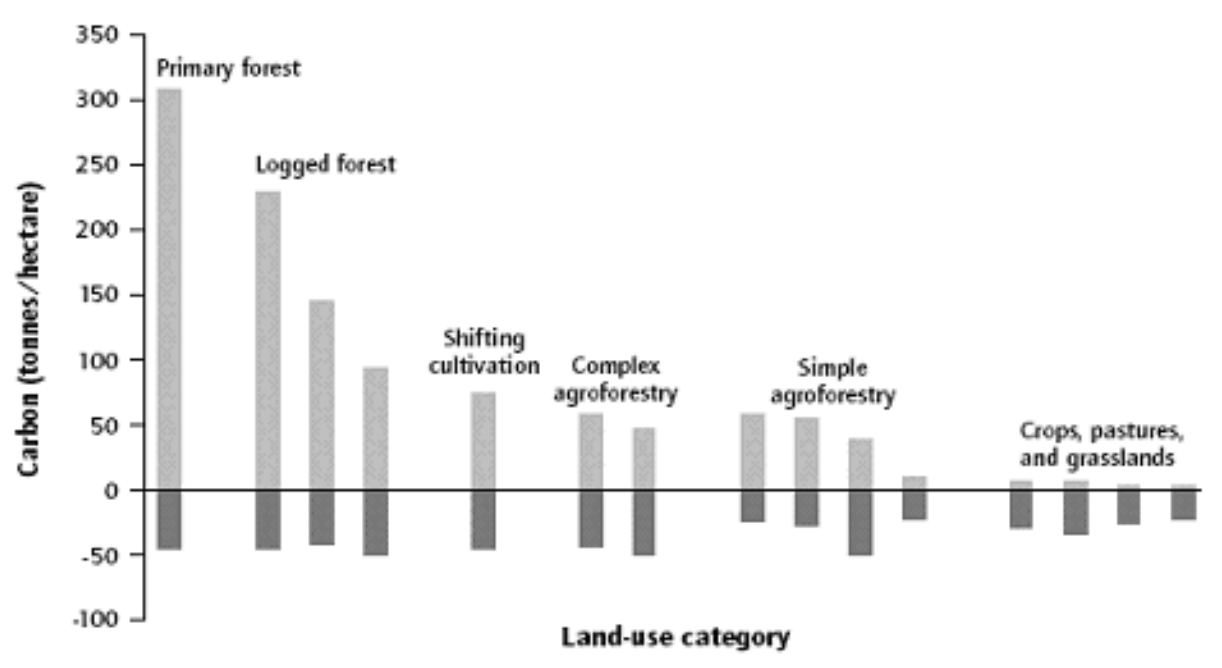

FIGURE 3. Carbon sequestration in the humid tropics by vegetation type

\section{Financeability of forest restoration}

Important services like oxygen, carbon abatement, mitigation of $\mathrm{CC}$ etc., will be accrued from forest restoration. Global efforts to raise fund, to finance these services are however yet to created a sizable volume of trade due to nonexcludability of the beneficiaries. There is also no competition amongst the beneficiaries as the forest services are, as of now, available abundantly. All these are proving to be hindrances for Financeability of non-economic services of the forest restoration, as the consumers/beneficiaries have no direct incentive to pay for the purveyors of forest restoration. The major traditional and some of emerging financial instruments that are available to promote forest services are shown in Table 5. 
TABLE 5. Instruments to promote forest ecosystem services

\begin{tabular}{|c|c|c|c|}
\hline Lead actors & Instrument & Examples & Who pays? \\
\hline Government & $\begin{array}{l}\text { Public direct } \\
\text { management of } \\
\text { forest resources }\end{array}$ & $\begin{array}{l}\text { National forests and } \\
\text { forest protected areas }\end{array}$ & $\begin{array}{l}\text { Government } \\
\text { (taxpayers) }\end{array}$ \\
\hline Government & $\begin{array}{l}\text { Regulation of } \\
\text { private forest } \\
\text { resource } \\
\text { management }\end{array}$ & $\begin{array}{ll}\text { Harvest } & \text { permits, } \\
\text { rules on logging } \\
\text { methods }\end{array}$ & $\begin{array}{lr}\text { Private } & \text { forest } \\
\text { owners } & \& \\
\text { managers } & \end{array}$ \\
\hline Government & $\begin{array}{l}\text { Support services } \\
\text { for forest } \\
\text { owners/users' } \\
\text { own initiatives }\end{array}$ & $\begin{array}{l}\text { Technical assistance } \\
\text { program for forest } \\
\text { owners to improve } \\
\text { management }\end{array}$ & $\begin{array}{l}\text { Government or } \\
\text { NGOs }\end{array}$ \\
\hline Government & $\begin{array}{lr}\text { Public pricing } \\
\text { policies } \\
\text { reflect } \\
\text { ecosystem costs } \\
\text { and benefits } \\
\end{array}$ & $\begin{array}{l}\text { Lower tax rate on } \\
\text { forested land }\end{array}$ & $\begin{array}{l}\text { Mixed: indirect } \\
\text { incentive } \\
\text { (outcome nor } \\
\text { measured) }\end{array}$ \\
\hline Government & $\begin{array}{l}\text { Open trading } \\
\text { deals under a } \\
\text { regulatory cap } \\
\text { or floor }\end{array}$ & $\begin{array}{lr}\text { Carbon trading } \\
\text { under the Kyoto } \\
\text { protocol }\end{array}$ & $\begin{array}{l}\text { Consumer or } \\
\text { producers subject } \\
\text { to cap (least cost) }\end{array}$ \\
\hline Government/Market & \begin{tabular}{lr}
\multicolumn{2}{l}{ Public payments } \\
to private land \\
and & forest \\
Owners & to \\
maintain & or \\
enhance & \\
ecosystem & \\
services & \\
\end{tabular} & $\begin{array}{l}\text { Agro-environment } \\
\text { payments for forest } \\
\text { conservation } \\
\text { easements on farms }\end{array}$ & Government \\
\hline Market & $\begin{array}{l}\text { Self-organizing } \\
\text { private deals }\end{array}$ & $\begin{array}{l}\text { Payments by a water } \\
\text { bottling company to } \\
\text { upstream watershed } \\
\text { managers }\end{array}$ & $\begin{array}{l}\text { Private company, } \\
\text { NGO, } \\
\text { community (user) }\end{array}$ \\
\hline Market & $\begin{array}{l}\text { Ecolabelling of } \\
\text { forest or farm } \\
\text { products }\end{array}$ & Forest certification & $\begin{array}{l}\text { Consumer, } \\
\text { immediately }\end{array}$ \\
\hline
\end{tabular}

Source: S. Scherr et al. (2004) 
The policy makers would not often consider these vital forest services in policy making. Moreover where the opportunity cost of land for forest (income from timber and NTFP) is less than for other projects like infrastructure, agriculture, real estates, industrial development, forests would be converted into these high opportunity cost projects. Hence, it is strongly advocated that national and international policy makers should consider vitality of the forest ecosystem and provide direct incentive in the form of generous budgetary support and allocation, and indirectly raise additional financial resources by way of levying cess and imposing indirect taxes for sustainable forest development. There is adequate global evidence that market based instruments are effective and efficient if they are designed meticulously for sustainable development (Pagiola et al. 2002).

\section{Estimated economic value of forest}

It was observed in India that out of the nine forest divisions surveyed only one division posted surplus. This was largely due to the non-accounting for benefits accruing from forests other than timber. If these divisions have taken into account the various services, using estimates proposed by Pearce \& Pearce (2001) (Table 6), than all these divisions may probably post surplus.

\section{CONCLUSION}

Climate change (CC), as an issue has risen from the annals of esoteric scientific discussion.

Automobile industry and users are one of the constituents that are responsible for CC. Forest restoration not only would clean the air of excess carbon, but may

\begin{tabular}{|c|c|}
\hline Forest good or service & $\begin{array}{l}\text { Tropical forests (US\$/ha/year } \\
\text { unless otherwise stated) }\end{array}$ \\
\hline \multirow[t]{2}{*}{ Timber } & \\
\hline & 200-4,400 (NPV) \\
\hline \multirow[t]{2}{*}{ Conventional logging } & 300-2,600 (NPC) \\
\hline & $20-440$ \\
\hline Sustainable & $30-266$ \\
\hline \multicolumn{2}{|l|}{$\begin{array}{l}\text { Conventional logging } \\
\text { Sustainable }\end{array}$} \\
\hline Fuel wood & 40 \\
\hline NTFPs & $0-100$ \\
\hline Genetic information & $0-3,000$ \\
\hline Recreation & $\begin{array}{l}2-470 \text { (general) } \\
750 \text { (forests near towns) } \\
1000 \text { (unique forests) }\end{array}$ \\
\hline Watershed benefits & $15-850$ \\
\hline Climate benefits & $\begin{array}{l}360-2,200 \text { (gross present } \\
\text { value) }\end{array}$ \\
\hline Non- use values & Not available \\
\hline Option values & $2-12$ \\
\hline Existence values & 4,400 (unique areas) \\
\hline
\end{tabular}

Source: Pearce \& Pearce (2001) as reproduced by S. Scherr, A. White \& A. Khare (2004). 
also mitigate the CC and also offers spin off benefits like meeting wood requirement of the society. World over about 25 hectares of forest cut down per minute, much of it in tropical developing nations. To compensate this massacre every minute US\$ 13500 , funds should be invested for long term sustenance of the forests and mitigating CC. Ministry of environment and forests government of India gets budget allocations, on an average 105.39 billion INR p.a. for last 15 years. To meet multiple objectives including mitigating CC forest restoration is essential. Thus in India the forestry restoration and CC fund can be created in lines with World Bank's climate investment fund. With the help of this fund forest restoration projects can be financed involving local communities though Joint Forest Management (JFM) committees and Community Forest Management (CFM) committees mechanism for effective and efficient forest restoration and inclusive development, that would eventually helps in mitigation and adoption measures of CC. All national and global agencies should strive to protect and enhance the health of primary forests and forest cover as it is not only the greater source of carbon sequestration and mitigating CC, but also provides many other vital services.

Automobile and electronics consumers in NCR area of India are willing to compensate for pollution created by them and contribute for the creation forest restoration and CC fund. Innovative financial instruments they preferred include that cess on petroleum products, investing in low coupon rate long term forestry bonds, direct green taxes and cess on income tax, in that order. More than half $(57 \%)$ of the respondents favoured introducing a compulsory investment in forestry bonds. Hence, policy makers can consider levying cess on petroleum products and issuing forestry bonds as sources for financing forest restoration fund. The awareness rate about pollution /GHG emission caused by them is $100 \%$ in automobile users and $92 \%$ in electronics goods consumption and $88 \%$ of the sample favoured both technology transitions (improvements) and forest restoration for carbon sequestration, as CC mitigation and adaptation measure which is in line with global preferences.

Enhanced budgetary allocations by all levels of governments, going to capital market with means such as long term bonds, coupled with income tax rebates, levying, forest cess on income tax, green tax on petroleum products, and automobile users and consumers of polluting electronics goods, compulsory investment in forestry bonds, etc. are innovative financial instruments for financing forest restoration activities. There is enough global evidence for deploying innovative financial instruments to finance forestry projects. Important services like, mitigation of CC will be accrued from forest restoration. Global and national level efforts to raise the fund, to finance forest restoration should be augmented. 


\section{References:}

CECILIA LUTTRELL, KATE SCHRECKENBERG and LEO PESKETT' 2007. The implications of carbon financing for pro-poor community forestry. Forestry Briefing 14 ,

Overseas Development Institute, London

E. SREEDHRAN 2009. Climate Change - An Opportunity for sustainable Development : The DMRC Experience. RITES journal July 2009, Pp.8.1-8.2.

GANDHI, R. 1989. Conservation for Development. In Tolba, M.K., and A.K. Biswas (eds.) 1991. Earth and Us. Better worth Heinemann, Kent.

GREEN CAR CONGRESS 2005. Pollution level remain high (or rising) in Indian cities, (on line) cited on 25th February , 2010, available from URLhttp://

www.greencarcongress. com / 2005/02/pollution_level.html.

IPCC, 2007: Climate Change 2007. Contributions of Working Groups I, II, and III to the Fourth Assessment, Cambridge University Press, Cambridge, UK

K. MANIVONG abd P SOPHATHILATH 2007. Status of community based forest management in Lao PDR. RECPFTC, Bangkok, Thailand and NAFRI, Vietiane, Lao PDR.Pp.31.

MOWEN J.C. 1987. Consumer Behaviour. Macmillan Publishing Company, New York.

OTTMAN. J.A. 1998. Green Marketing. NTC Illionois.

PETER J.P. and J.C. Olson. 1990. Consumer Behaviour, Irwin, Boston

SCHIFEMAN, L.G., and L. LABARKARU. 1990. Consumer Behaviour. Prentice-Hall of India, New Delhi.

Scherr, S., A. White \& A. Khare, 2004. For Service Rendered, Technical report 21, International Tropical Timber Organization (ITTO), Yokohama, 220-0012, Japan, pp . $23,25,38,41,45$

SHIVA, M.P. and I. JANTAN. 1998. Non-Timber Forest Products from Dipterocarps. In Simmathiri Appanah andvJennifer M. Turnbull, eds. A Review of Dipterocarps

Taxonomy,

ecology and silviculture, Center for International Forestry Research Bogor, Indonesia, Forest Research Institute Malaysia, pp.187-197.

SHRIVASTAVA, M.B. 1997. Wood Wood Technology. Vikas publishing House

New Delhi.

THE WORLD BANK GROUP 2009. Development and climate change, Washington, DC,

USA

WORLD WIDE FUND WWF, report 1998

YEBOAH, R. 2001. Sustainable forest management in Ghana. In proceedings of Tropical forestry symposium: The art and practice of conservation planting, Taipei, Taiwan, pp.88. 


\section{ANNEXURE 1}

SUPPORTING CLIMATE ACTION BY THE PRIV ATE SECTOR: IFC AND $M I G A$

IFC's approach to climate change focuses on enhanced support for investments in renewable energy and energy efficiency, partnerships to address climate change mitigation and adaptation, and extending carbon finance activities. IFC will increase its investment support, with the aim for a catalytic role for facilitating the transfer of appropriate technologies and approaches to the private sector in developing countries. IFC's Cleaner Production program already actively analyzes opportunities for implementation of energy efficiency processes in IFC's pipeline and portfolio projects. With its flagship Carbon Delivery Guarantee product, IFC assures delivery of carbon credits from companies in developing countries to buyers in developed countries that can help clients maximize the potential for clean energy and other climate friendly and low carbon investments. The GEF/IFC Earth Fund with an initial funding of US\$40 million, of which GEF provides US\$30 million, will fund a portfolio of projects that contribute to climate-friendly market transformation. MIGA developed an innovative non-commercial insurance instrument to mitigate a series of risks to carbon finance project performance that was first applied for a landfill gas flaring project in San Salvador. It is increasing its support to clean and renewable energy. The current pipeline of applications is US $\$ 600$ million, with about US $\$ 280$ million expected to close in fiscal year 2009. MIGA plans to develop new products to address political and regulatory risks associated with climate change, and intensify awareness raising and capacity building.

Source: The WBG. 
ANNEX 2
COSTS AND FINANCING SOURCES

\section{TABLE A2:1 GLOBAL ESTIMATES OF COSTS AND INVESTMENT REQUIREMENTS FOR MITIGATION}

$\begin{array}{ll}\text { Study } & \text { Estimate } \\ \text { WBG, Clean Energy } & \text { US\$30 billion/ annum for } \\ \text { Framework } 9 & \text { power sector in developing } \\ 04 / 2006 & \text { countries }\end{array}$

Stern Review 10

$11 / 2006$
US\$1,000 billion/annum

\section{Basis}

Investment estimate, assuming stabilization at $450 \mathrm{ppm}$, on top of US\$160 billion per year for electricity supply in developing countries over 2010-30, of which currently only half is financed

Annual global macroeconomic cost; central estimate by 2050 , consistent with stabilization at $550 \mathrm{ppm}$; represents $1 \%$ of global GDP by 2050 , ranging from net gains of $1 \%$ global GDP to reduction of $3.5 \%$

UNFCCC11

US\$200-210 billion/annum

Estimate of annual global investment and financial flavs by 2030 , broadly consistent with stabilization at $550 \mathrm{ppm}$

$08 / 2007$

$5.5 \%$ to $-1 \%$ (gain)

reduction in global GDP
Estimate of annual macroeconomic costs to global GDP, ranging from $3 \%$ to small increase by 2030 and from $5.5 \%$ to $1 \%$ gain by 2050 for targets between 445 to $710 \mathrm{ppm}$

$\begin{array}{lll}\text { OECD Environmental } & \text { US } \$ 350-3,000 & \text { Annual global macroeconomic cost, central estimate, } \\ \text { Outlook to } 2030^{13} & \text { billion/annum } & \text { consistent with stabilization at } 450 \text { ppm; represents a } 0.5 \% \\ 05 / 2008 & & \text { loss to global GDP by } 2030 \text { and } 2.5 \% \text { by } 2050 \text { or an } \\ & \text { average } 0.1 \% \text { slow down of growth }\end{array}$

IEA Energy Technology

Perspectives 200814

$06 / 2008$
US\$400-1,100

billion/annum

for energy sector
Global cumulative additional investment needs between naw and 2050 for energy sector estimated at US\$17 trillion, or $0.4 \%$ of global GDP ( 550ppm) and US\$45trillion, or 1.15 of global GDP ( 450ppm)

9 See World Bank (2006). Clean Energy and Development: Towards an Irvestment Framework, available at http//siteresourcesworldbank.org/ DEVCOMMINT/Documentation/20890696/DC2006-0002(E)-CleanEnergy.pdf

10 Nicholas Stern (2007). The Economics of Climate Change: The Stern Review. Cabinet Office - HM Treasury, at http $/$ /Www.hm-treasury.gov.uk/independent_reviews/stern_review_economics_climate_change/stern_review_Report.cfm

11 Source: "Dialogue on long-term cooperative action to address climate change by erhancing implementation of the Corvention" Dialogue working paper $8(2007)$, at http://unfcocint/files/cooperation_and_support/financial_mechanism/financial_mechanism_gef/ application/pdf/dialogue_working_paper_8.pd

12 See the IPCC Fourth Assessment Report Synthesis Report, at http://wow.ipcc.ch/pdt/assessment-report/ar4/syr/ar4_syr.pdf

13 See OECD (2008). OECD Ervirormental Outlock to 2030, at http $/ /$ wow.oecd.org/ervironment/cutbolto2030

14 IEA (2009). Energy Technology Perspectives 2008: Scenarios and Strategies to 2050, at http:/www.iea.org/w/bockshop/add. aspx?id=330 


\section{TABLE A2:2 ESTIMATES OF COSTS AND INVESTMENT REQUIREMENTS FOR ADAPTATION IN DEVELOPING COUNTRIES}

\begin{tabular}{|c|c|c|c|}
\hline $\begin{array}{l}\text { Study } \\
\text { Total adaptation costs }\end{array}$ & Date released & Estimate & Basis \\
\hline Various academic & 1990 s on & Various & $\begin{array}{l}\text { Usually sectoral and long term-for instance, end of century- } \\
\text { and with widely differing assumptions }\end{array}$ \\
\hline $\begin{array}{l}\text { World Bank (CEIF) } \\
\text { as revised by the }\end{array}$ & $04 / 2006$ & $\begin{array}{l}\text { US\$4-37 } \\
\text { billion/annum }\end{array}$ & $\begin{array}{l}\text { Irvestment to "climate proof" all adaptation-related activities in } \\
\text { developing countries }\end{array}$ \\
\hline Stern Review & $11 / 2006$ & & \\
\hline IPCC & $4 / 2007$ & & $\begin{array}{l}\text { No new estimates, but argue that most studies show a high } \\
\text { benefit-cost ratio for adaptive actions }\end{array}$ \\
\hline Oxfam & $5 / 2007$ & $\begin{array}{l}\text { US\$8-33 } \\
\text { billion }\end{array}$ & $\begin{array}{l}\text { Costs of immediate priorities similar to those in national } \\
\text { adaptation programs of action (NAPAs) applied to all } \\
\text { developing countries }\end{array}$ \\
\hline UNFCCC & $10 / 2007$ & $\begin{array}{l}\text { US\$28-67 } \\
\text { billion in } 2030\end{array}$ & $\begin{array}{l}\text { Imvestment needs for adaptation activities in developing countries } \\
\text { in } 2030 \text {-all sectors, private and public }\end{array}$ \\
\hline UNDP (HDR 2007-08) & $01 / 2008$ & $\begin{array}{l}\text { US\$86 } \\
\text { billion/annum } \\
\text { by } 2016\end{array}$ & $\begin{array}{l}\text { "New and additional" finance for adaptation through transfers } \\
\text { from rich to poor by } 2016 \text { to protect progress towards the MDGs } \\
\text { and prevent post- } 2015 \text { reversals in human development }\end{array}$ \\
\hline
\end{tabular}

Note: It should be noted that the adaptation estimates are less advanced and reliable, and carnot be directly compered with the mitigation cost estimates. 


\section{TABLE A 2:3 EXISTING RESOURCES AND FINANCING INSTRUMENTS DEDICATED TO CLIMATE CHANGE}

Financing Source

\section{Fnancing Source}

\section{CDM}

Value of Primary CDM transactions:

US\$7.4 billion in 2007, estimated to

leverage US\$36 billion 15

GEF TF
US\$250 million p.a.
$(2006-2010)$

\section{Other}

Trust Funds and Partnerships housed in MDBs

\section{Role/Scope}

\section{MITIGATION}

Improves financial returns through long-term purchase agreements for the GHG emissions reductions resulting from climate-friendly projects

\begin{abstract}
Finances incremental costs of removing barriers to market development of near commercial technologies, institutional development, innovation, piloting, and demonstration
\end{abstract}

Grant financing for climate change knowledge products, capacity building, upstream project work or pilots

\section{ADAPTATION}

Adaptation Fund-US\$80 million to US\$1 billion million per annum by 2012 (best estimate: US $\$ 300$ to US\$500 million)

\begin{tabular}{|c|c|}
\hline $\begin{array}{l}\text { UNFCCC Special Funds } \\
\text { (administered by GEF) }\end{array}$ & $\begin{array}{l}\text { LDCF helps in the preparation and financing of implementation of national } \\
\text { adaptation programs of action (NAPAs) to address the most urgent }\end{array}$ \\
\hline Least Developed Countries Fund (LCDF) $\approx$ & adaptation needs in the least developed countries \\
\hline Special Climate Change Fund (SCCF) $\approx$ & SCCF supports adaptation and mitigation projects in all developing \\
\hline US\$90 million & countries, with a large emphasis on adaptation \\
\hline Strategic Priority to Pilot an Operational & SPA is a funding allocation within the GEF Trust Fund whose objective is to \\
\hline Approech on Adaptation (SPA)— & support pilot and demonstration projects that address local adaptation \\
\hline US\$50 million till 2010 & needs and generate global environmental benefits in all GEF focal areas \\
\hline $\begin{array}{l}\text { Global Facility for Disaster Reduction } \\
\text { and Recovery (GFDRR) }\end{array}$ & $\begin{array}{l}\text { Partnership within the UN International Strategy for Disaster Reduction } \\
\text { (ISDR), focusing on building capacities to enhance disaster resilience and }\end{array}$ \\
\hline
\end{tabular}

UNDP

Adaptation facilities for Africa: US\$90-120 million
Funding for the Adaptation Fund will mainly come from a 2 percent levy on revenues generated by the CDM
LDCF helps in the preparation and financing of implementation of national adaptation programs of action (NAPAs) to address the most urgent adaptation needs in the least developed countries

SCCF supports adaptation and mitigation projects in all developing countries, with a large emphasis on adaptation

SPA is a funding allocation within the GEF Trust Fund whose objective is to support pilot and demonstration projects that address local adaptation Partnership within the UN International Strategy for Disaster Reduction (ISDR), focusing on building capacities to enhance disaster resilience anc adaptive capacities in changing climate 


\section{TABLE A2:3 CONTINUED}

Other

ADB: US\$40 million initial capitalization

Bilateral resources (e.g., adaptation programs run by national development assistance institutions)

CGIAR: Climate-related research for agriculture US\$77 million ( $€ 50$ million)

Trust Funds and partnerships housed in MDBs
Grants for climate change knowledge products, capacity building, upstream project work or pilots

\section{BLENDED RESOURCES FOR MITIGATION \& ADAPTATION}

Climate Investment Funds $\approx$ US $\$ 6$ billion

Two trust funds will be created under the Climate Imvestment Funds:

- The Clean Techndogy Fund will provide new, large-scale financial rescurces to invest in projects and programs in developing countries which contribute to the demonstration, deployment, and transfer of low-carbon technologies. The projects or programs must have a significant potential for long-term greenhouse gas savings.

- The second fund, the Strategic Climate Fund, will be broader and more flexible in scope and will serve as an overarching fund for various programs to test innovative approaches to climate change. The first such program is aimed at increasing climate resilience in developing countries.

EC Global Climate Change Alliance (GCCA) $\approx$ US\$450 million ( $€ 300$ million)

- Thematic Program for Environment and Sustainable Management of Natural Resources (including Energy)—managed by the European Commission DG Development/ EuropeAid ( $€ 110$ million)

- European Development Fund—managed by DEV/AIDCO—budget framework 2008-13 ( $€ 280$ million)

\section{Notes:}

- The GEF is the largest source of grant-financed mitigation resources, with about US\$250 million per year going to mitigation activities over 2006-10. 16

- The CDM unambiguously dominates the project-based market, with more than 1.5 billion Certified Emissions Reductions (CERs) transacted from 2002 orward for a cumulative value exceeding US\$16 billion, estimated to have leveraged US\$59 billion. JI and AAU/GIS transactions could also contribute to leverage financing for climate action, particularly in Europe and Central Asia countries. There are currently at least 17 funds and facilities managed by MDBs totaling close to US\$3 billion, of which a large part (about two-thirds) is already committed.

- With respect to adaptation, multilateral funds are expected to contribute slightly more than half a billion US dollars over the next few years. Financial rescurces that will be made available through the Adaptation Fund are difficult to quantify, and could be in the range of US\$300-500 million per year until 2012. Adding all possible sources of financing (including bilateral funds and the EC GCCA fund) is difficult due to lack of firm estimates from many new sources, but the total amount appears unlikely to exceed US\$1 billion per year in the next several years.

16 In addition, some US\$15 million from the Special Climate Change Fund (a GEF-administered UNFCCC Special Fund) are available for technology transfer. With respect to World Bank engagement against climate change, cumulative GEF resources committed to mitigation projects reached US\$1.64 billion at mid-FYas, with a leverage (on IBRD/IDA resources) of roughly 2.2 . 
